\title{
KRITIK SASTRA MARXIS FREDRIC JAMESON: TEORI DAN APLIKASINYA
}

\author{
Ramayda Akmal \\ Sastra Indonesia Fakultas Ilmu Budaya UGM \\ Jln. Sosiohumaniora, Bulaksumur, Yogyakarta \\ Email: ramaydaakmal@gmail.com
}

\begin{abstract}
Abstrak
Tulisan ini merupakan pembacaan dan penyusunan kembali konsep dan gagasan yang dikembangkan oleh Fredric Jameson dalam ranah kesastraan. Bersumber pada tiga buku utamanya, yakni Marxism and Form, The Political Unconscious dan Postmodern, or The Logic of Cultural Late Capitalism, tulisan ini memformulasikan gagasan Jameson sehingga menghasilkan satu kerangka teoretik dan metodologis yang runut. Dengan sumber yang sama pula, gagasan umum yang mempengaruhi dan memberikan landasan dasar bagi pemikiran Jameson seperti marxisme, psikoanalisis dan posmodern akan dikemukakan.
\end{abstract}

Kata Kunci: Fredric Jameson, Marxisme, Karya Sastra

\section{Abstract}

This paper is a review and preparation of concepts and ideas developed by Fredric Jameson in the realm of literature. From three main books, namely Marxism and Form, The Political Unconscious and Postmodern, or The Cultural Logic of Late Capitalism, Jameson this paper formulated the idea to produce a theoretical and methodological framework trace. With the same source as well, affecting the general idea and provide the basic foundation for thinking Jameson as Marxism, psychoanalysis and postmodernism will be presented.

Keywords: Fredric Jameson, Marxism, Literary Works

\section{Pendahuluan}

Fredric Jameson merupakan salah satu kritikus Marxis terpenting sejak beberapa dekade terakhir. Objek kajiannya begitu luas, mulai dari arsitektur hingga sain fiksi, dari novel-novel abad ke-19 hingga film-film kontemporer, dan dari filsafat hingga karya seni avant-garde. Keluasan jangkauan yang tidak hanya ada pada level jenis tetapi juga pada level waktu menjadi alasan paling utama untuk menelusuri pemikiran-pemikirannya secara terperinci. Keluasan dan kekayaan konsepnya itu merupakan kelebihan di satu sisi, tetapi juga kerentanan di sisi yang lain. Sebab, analisisnya yang luas dan style penulisannya yang rumit sering kali mengaburkan pemahaman pembaca dalam menelaah pemikiran-pemikirannya, lebih-lebih untuk menemukan metodologi yang ia gunakan dalam analisisnya.

Salah satu cara untuk memaksimalkan pembacaan terhadap pemikiran Jameson adalah dengan menguraikannya dalam satu fokus pembahasan tertentu yang ditentukan misalnya oleh objek analisisnya. Tulisan ini mencoba untuk merealisasikan cara itu dengan memetakan pemikiran Jameson yang ia gunakan secara khusus untuk menganalisis karya sastra. Oleh karena itu, setelah melakukan penelusuran terhadap gagasan-gagasan dasar yang membentuk bangunan teoretiknya secara umum, tulisan ini akan menghadirkan ringkasan analisis Jameson terhadap karya sastra atau fenomena kesastraan tertentu untuk kemudian menemukan benang merah metodologisnya sehingga bisa menjadi model analisis dalam konteks kesusastraan Indonesia.

\section{Perkembangan Pemikiran (dalam Karya) Fredric Jameson}

Ada beberapa karya Jameson yang menjadi rujukan utama tulisan ini. Karya-karya tersebutjuga sekaligus menandai perkembangan pemikiran Jameson. Buku pertama yang membuat reputasinya meningkat, dan yang 
menjadi salah satu rujukan tulisan ini adalah Marxisme and Form (1971). Buku ini menguraikan secara detil keberadaan dan peran teoretikus kontinental serta pemikir-pemikir tradisi Marxis. Dalam buku ini Jameson menguraikan gagasan individualnya tentang posisi dan kinerja kritikus kala itu. Menurut Jameson, kritikuskritikus perlu berkonsentrasi pada bentuk dari karya sastra setara dengan bagaimana mereka meneliti kontennya. Bentuk bukan hanya pelengkap atau hiasan sebuah karya, melainkan juga perwujudan dari pesan-pesan ideologis yang kuat. Teorinya tentang bentuk dan isi ini secara konsisten dipertahankan dalam analisisanalisis selanjutnya.

Setelah Marxisme and Form, secara berturut-turut terbit beberapa publikasi yang semakin menegaskan pemikiran-pemikiran Jameson. Buku The Political Unconscious (1981) dapat dikatakan menjadi teks Marxisme dalam lingkup sastra dengan teori yang cukup luas yang diaplikasikan secara komprehensif. Pada bagian inti tulisan ini, akan disampaikan beberapa ringkasan analisis Jameson dalam buku The Politic Unconscious untuk kemudian dirumuskan kerangka kerjanya. Yang menarik, buku ini juga menandai munculnya atau meningkatnya fenomena posmodernitas yang kemudian Jameson tegaskan dalam artikelnya di jurnal New Left Review berjudul "Postmodern, or the Culture Logic of Capitalism" (1984). Artikel ini kemudian dibukukan dengan artikelartikelnya yang lain dengan judul sama pada tahun 1991, dan menjadi salah satu buku kritik budaya terpenting pada dekade 1990an.

Walau berbicara posmodernisme dalam tulisan-tulisannya tersebut, Jameson tidak pernah beranjak dari posisinya sebagai seorang kritikus Marxis. Demikian pula ketika ia meluaskan jangkauan pemikirannya pada analisis film dan produksi budaya. Buku Signatures of The Visible (1990) merupakan buku Jameson tentang bagaimana membaca sinema dan teks-teks sinematik. Sementara itu, kritik Jameson terhadap sinema-sinema yang terperangkap dalam kapitalisme global dituangkan dalam The Geopolitical Aesthetic:
Cinema and Space in the World System (1992). Perspektif Marxis dalam memandang fenomena posmodernitas kemudian dapat dikatakan menjadi bingkai pencapaian intelektual Jameson yang paling kontemporer. Kadangkala dua pemikiran tersebut berjalan pada satu garis historis, kadangkala dominan di satu sisi atau tampak terpisah sama sekali. Dan bukunya yang berjudul The Seed of Time (1994) merupakan buku mutakhir Jameson yang berisi pembacaannya tentang posmodern di satu sisi dan gagasan Utopia khas Marxis di sisi lain dalam kolaborasi yang mengagumkan.

Karya-karya Jameson di atas perlu diungkapkan sebagai landasan untuk memahami perkembangan pemikiran sekaligus konsistensinya dalam mencermati berbagai fenomena yang ada. Dari karya-karyanya itu diketahui bahwa teori Jameson bersandar setidaknya pada tiga terma besar, yakni marxisme, posmodernisme, dan psikoanalisis. Jameson adalah Marxis sejati yang secara konsisten menerapkan gagasan-gagasannya terhadap seluruh aspek bahkan terhadap apa yang dinamakan posmodernisme. Namun, Jameson sekaligus juga menformulasikan kembali dua konsep itu menjadi khas dan identik dengan dirinya. Analisis Jameson terhadap karya sastra misalnya, kemudian mensyarakatkan rekonseptualisasi yang memang dilakukan Jameson terhadap dua gagasan besar di atas. Oleh karena itu, terlepas dari konteks sastra, Jameson juga menjadi pemikir Marxis dan posmodernis yang penting.

Selain dua gagasan besar itu, Jameson juga banyak mengadaptasi konsep-konsep yang dicetuskan Sigmund Freud dan Jacques Lacan. Konsep-konsep yang tergabung dalam bangunan teori psikoanalisis ini digunakan Jameson untuk menjelaskan sifat-sifat relasi antara struktur-struktur dalam masyarakat yang dirumuskan oleh Marx, yang bagi Jameson memiliki keterkaitan erat dengan karya sastra atau produk budaya yang lain.

Seperti diungkapkan di awal bahwa tujuan utama tulisan ini adalah merumuskan teori Jameson dalam konteks kesastraan, maka 
ketiga gagasan utama yang membangun teori Fredric Jameson tadi juga akan dikemukakan dalam konteks tersebut. Oleh karena itu, tulisan ini hanya akan menjadikan tiga buku yang disebutkan pertama sebagai sumber utama uraian, karena ketiga buku itulah yang secara dominan menjadikan karya sastra sebagai topik dan fokus analisis. Namun sebelum sampai pada uraian tentang bagaimana Jameson mengaplikasikan teorinya dalam karya sastra, di bawah ini dirumuskan secara singkat bangunan dasar gagasan-gagasan Jameson yang mengambil peran dalam level motif (konsep dan cita-cita Marxis), pada level metodis (konsep-konsepnya Freud dan Lacan) dan pada level diskursif (konsep posmodernisme).

\section{Marxisme Jameson}

Ada beberapa area dari pemikiran marxisme yang sangat erat kaitannya sekaligus berbeda perkembangannya dalam gagasan Jameson. Pertama-tama adalah gagasan tentang totalitas, di mana segala yang ada sebagai superstructure ditentukan seluruhnya oleh basestructure. Seperti halnya Althusser, Jameson juga mendekonstruksi pemahaman tentang totalitas. Ekonomi (base-structure) adalah relatif. Yang dasar itu kadang determinan terhadap supestructure, tetapi bisa pula sebaliknya dan mungkin bebas relasi satu dengan yang lain. Kerelatifan ini juga bisa digunakan untuk melihat produksi budaya seperti film.

Sebagai contoh, film Titanic (1997) bukan sekadar representasi tentang permasalahan kelas, bukan pula tentang bagaimana kaum kapitalis melenakan rakyat dengan cerita romantik agar terlupa akan kondisi ekonomi yang tidak adil. Yang lebih penting dari film itu berdasarkan gagasan Althusser yang diadopsi Jameson adalah kontradiksi-kontradiksi, gap serta ketegangan-ketegangan yang terjadi antara berbagai kelas di dalamnya, juga keberadaan berbagai struktur yang terhubung dalam kompleksitas, bukan sekedar elemen dari sebuah totalitas tertentu.

$$
\text { Jameson mengelaborasi gagasan }
$$

Althusser di atas untuk melihat hubungan antara badan produksi sastra pada akhir abad ke-19 dengan kecenderungan bentuk karya sastra yang muncul pada waktu yang sama. Perubahan tipe novel dari yang menonjolkan hal-hal romantik menuju ke novel-novel yang lebih realistis harus dikaitkan dengan perubahan tatanan ekonomi yang mempengaruhi industri penerbitan. Dalam konteks itu, aspek ekonomi menjadi determinan dalam pergeseran bentuk novel, walaupun bagi Jameson itu hanya satu subsistem dari tatanan kehidupan sosial budaya masyarakat yang kompleks kala itu (Jameson, 1981: 26).

Selain determinasi dan kekompleksan hubungan di atas, Jameson juga menekankan pentingnya kesadaran historis. Bagi Jameson, masa kini adalah situs yang diperebutkan oleh masa lalu dan masa depan. 'Sekarang' adalah komposit dari jejak-jejak lalu yang mengantisipasi kehadiran masa depan dalam mode produksi kontemporernya. Jameson menentang Marxisme vulgar yang menganggap sejarah bergerak dalam hukum materialisme dialektik dan perjuangan kelas. Sejarah yang alegorik, di mana basis dicerminkan oleh superstruktur adalah hal yang sangat tidak disetujui Jameson. Menjadi sangat reduksionis ketika melihat teks sebagai model alegoris dari sebuah masyarakat secara keseluruhan, baik elemen-elemen maupun tanda-tandanya.

Lalu Jameson memberikan model yang berbeda dari hubungan determinatif marxisme vulgar seperti di bawah ini.

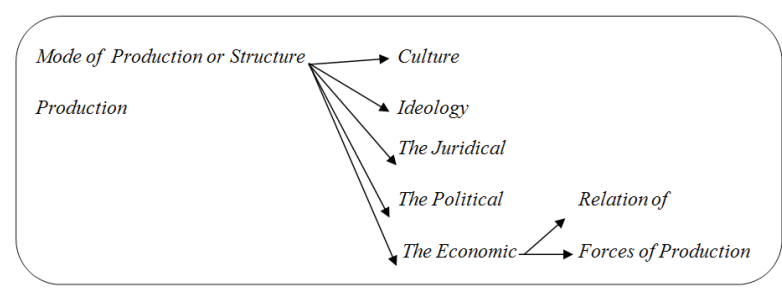

Dari cabang-cabang di atas tampak bahwa aspek-aspek dalam masyarakat seperti budaya atau hukum tidak secara langsung dideterminasi oleh ekonomi, bahkan aspek tersebut "semi otonom".

Selain koreksinya terhadap sejarah dan semantik naif di atas, Jameson juga 


\section{Jurnal Poetika Vol. 1 No. 1, Juli 2013}

mengembangkan konsep yang dicetuskan oleh Lukacs, reification, dan konsepnya Adorno tentang commodification. Bagi Lukacs, reifikasi menjadi sangat penting, karena menjadi akar dari banyak permasalahan masyarakat kontemporer. Reifikasi ini bekerja melalui dua jalan. Pertama, reifikasi dilakukan ketika kapitalisme mendefinisikan segalanya sebagai komoditas dan memiliki nilai tukar. Sesuatu (yang dinilai dengan uang) lebih penting daripada eksistensi seseorang. Kedua, reifikasi menandakan kemenangan komoditas dan kemunduran sense of society sebagai sebuah kesatuan organik. Keutuhan itu hancur menjadi penyebaran sporadis spesialisasi-spesialisasi. Mesin dan objek-objek teknis mendominasi keberadaan aktual manusia.

Bagi Jameson, konsep reification sangat kontekstual untuk melihat masyarakat yang didominasi budaya kapitalisme lanjut. Reifikasi menghancurkan sense of totality dalam sebuah masyarakat. Ia memfragmentasikan persepsi manusia terhadap keseluruhan dunia di mana mereka hidup. Keberadaan manusia sebagai individu hanya bisa diekspresikan melalui komoditas. Dan bagi Jameson, seni memiliki peranan penting dengan potensi kemampuannya untuk melawan kekuatan reifikasi dalam masyarakat konsumtif dan untuk menemukan kembali kategori totalitas di manasa secara sistematis telah dihancurkan oleh eksistensi terfragmen dalam setiap level kehidupan (Jameson, 1988: 146).

Bagaimana seni bisa melakukan peran itu? Jameson mengadopsi teori Adorno tentang komodifikasi untuk menjelaskan kemungkinan tersebut. Menurut Adorno, budaya telah diracuni oleh kapitalisme dan menjadi industri kultural. Asumsi ini dituangkan dalam buku kolaborasinya dengan Marx Horkheimer, The Dialectic of Enlightment (1944). Dalam buku ini Adorno menyebut bahwa budaya populer Amerika tahun 1930an-1940an menjemukan dan bersifat repetitif. Pada kesimpulannya, secara sederhana repetisi yang terjadi pada musik dan film misalnya, menjadi alat opresi sosial untuk mengkondisikan masyarakat agar menerima hidup dan pekerjaan-pekerjaan yang juga repetitif sebagai sesuatu yang natural.

Dalam ranah kesusastraan, Adorno melihat bahwa karya sastra yang memungkinkan melakukan perlawanan terhadap kondisi di atas bukanlah karya para naturalis seperti Emile Zola, melainkan karya-karya Beckett yang menghadirkan bahasa-bahasa sulit dan gaya eksperimental. Seperti Adorno, Jameson juga lebih menekankan keberadaan bentuk dari karya seni-genre, struktur, gaya-dibandingkan isi-cerita, karakter, latar. Akan tetapi, hal ini bukan berarti isi tidak penting. Bagi Jameson aspek formal sebuah karya memiliki potensi revolusioner lebih besar, inovasi dalam bentuk karya merepresentasikan aspek progresif darinya.

Jameson meneruskan kemungkinan ini dengan memformulasikan gagasannya, bahwa bentuk lebih signifikan dibandingkan isi. Ia mengambil contoh analisis panjang Lukacs mengenai bentuk novel dan totalitas masyarakatnya. Menurut Lukacs, ada koherensi antara bentuk epic Yunani yang utuh dengan totalitas organik kebudayaan Yunani. Kondisi ini berbeda dengan yang terjadi pada novelnovel abad ke-19. Novel-novel ini tidak mampu menggambarkan sesuatu yang bernama totalitas sebab masyarakat yang melahirkannya secara radikal telah terfragmentasi dan rapuh oleh proses reifikasi yang terjadi akibat kapitalisme. Novel-novel itu mengandung estetika yang terfragmentasi. Bentuk-bentuk estetis ini lebih penting dibandingan cerita-cerita di dalamnya yang seringkali konvensional dan eskapis.

Reifikasi yang menghasilkan fragmentasi dan destruksi terhadap totalitas eksistensi harus dilawan. Seni dan sastra menjadi hal yang vital bagi para Marxis karena memiliki kemampuan untuk menyediakan makna-makna baru yang menyegarkan sense of totality masyarakat, dan yang lebih penting dapat secara aktif melawan fragmentasi terhadap eksistensi masyarakat tersebut. Salah satu cara untuk melakukan deotomatisasi terhadap proses reifikasi ini adalah melalui proses dialektika.

Bagi Jameson, dialektik adalah tataran 
metakritik dari sebuah mode berpikir, jalan di mana sebuah kritik untuk juga selalu mewaspadai dirinya sendiri. Menurut Jameson, dialectical thinking is a thought to the second power, a thougt about thinking itself, in which the mind must deal with its own thought process just as with the material works on (Jameson, 1971:45).

Dialektika ini bisa digunakan dalam melihat dua konsep besar dari kapitalisme yang mendukung reifikasi, yakni identitas dan standardisasi. Bagi Adorno, yang dikutip Jameson, sesuatu yang diberi identitas kemudian adalah sesuatu yang identik dengan yang lain. Lingkungan kapitalisme, dengan uang yang ada di dalamnya, menggantikan seluruh variasi dan perbedaan yang ada pada setiap kemanusiaan. Adorno sangat melawan proses identitas ini dan wajah sehari-hari yang sudah dinamai, mengalami repetisi dan menjadi seragam, dengan segenap kerusakan psikologisnya. Identitas yang demikian terjadi pada masyarakat dari level atas hingga bawah sehingga melawannya tidak bisa dengan tindakan-tindakan sesaat yang tidak tersistem. Harus ada penolakan dialektik dan tersistem, yang kemudian dirumuskan Adorno sebagai negative dialectics.

Adorno menolak pemahaman dialektik kuno yang mengemukakan bahwa dialektika adalah mendapatkan hal positif melalui proses negasi. Adorno tidak percaya dengan kepositifan itu karena kenyataannya hal itu tidak mampu melawan 'identitas' yang diberikan kapitalisme. Adorno berupaya membebaskan proses dialektik dari afirmasi kapitalisme itu. Dalam konteks kesusastraan, dialektika itu kemudian diterjemahkan sebagai dekonstruksi. Namun demikian, Jameson dengan jelas menarik garis perbedaan antara negative dialectic-nya Adorno dengan pendekatan dekonstruksi yang banyak digunakan ahli-ahli posmodernis non-Marxis. Bagi Jameson, metode Adorno memiliki basis motivasi Marxis dengan tujuan yang selalu sama, membongkar opresi-opresi dari kapitalisme.

Proses dialektik dan berbagai cara yang diformulasikan Jameson untuk menemukan determinasi kapitalisme dalam karya sastra atau kesusatraan harus ditemukan atau terkait erat dengan proses intepretasi. Fundamen marxisme, memberikan kaitan abadi antara sebuah karya dengan sejarahnya. Sementara untuk menemukan sekaligus mengemansipasi teks-teks dari tekanan reifikasi kapitalisme, dibutuhkan proses interpretasi kritis. Oleh karena itu, langkah awal untuk memahami kerja Jameson adalah dengan menyadari bagaimana sejarah yang tergambar dalam sebuah karya direpresentasikan.

Para Marxis, termasuk Jameson di dalamnya, meyakini bahwa dunia tidak hanya seperti apa yang kita lihat, gabungan dari berbagai fakta yang ada, melainkan sudah melalui proses intepretasi. Kita memahami dunia yang sudah diintepretasikan. Proses ini kemudian tergantung pada ideologi dominan dalam masyarakat di mana kita tinggal. Oleh karena itu, seseorang yang hendak mengetahui bentuk-bentuk intepretasi harus memahami ideologi yang bekerja pada lingkungan sekitar objek yang diintepretasi tersebut.

Jameson memberikan kontribusi penting dalam proyek intepretasi ini. Ia merumuskan semacam pertanyaan-pertanyaan metakritik atas politik intepretasi. Disebut metakritik karena usulan Jameson merupakan kritik atas kritik. Ia selalu meyakini bahwa segala bentuk intepretasi yang kemudian diwujudkan dalam sebuah kritik memiliki dimensi politik di dalamnya. Kritik terbentuk dalam rangka seseorang berhubungan dengan orang lain, terbentuk oleh realitas sosio-ekonomi yang terletak dan menentukan terjadinya hubungan itu.

Politik intepretasi ini kemudian berhubungan erat dengan sejarah. Jameson meyakini bahwa sejarah dibentuk oleh intepretasi-intepretasi. Oleh karena itu, diperlukan kewaspadaan ketika memahami berbagai narasi yang terkandung dalam sejarah. Namun, intepretasi-intepretasi juga dipengaruhi oleh keberadaan sejarah yang mendahuluinya. Kerelatifan yang sangat tinggi dan hubungan respirokal terkait dengan keberadaan sejarah dan intepretasi ini memunculkan pertanyaan 
mengenai bagaimana cara menemukan narasi yang paling tepat? Takaran apa yang digunakan untuk membandingkan intepretasi satu dan yang lainnya? Seorang dekonstruktivis akan menjawab bahwa tidak ada kebenaran absolut. Marx sendiri mengembalikan segalanya kepada aspek ekonomi. Sementara Lukacs, secara lebih spesifik mengakarkan intepretasi kepada kelas proletariat industrial. Jameson sendiri, berbeda dengan banyak Marxis lainnya, merujuk segala bentuk intepretasi pada sejarah. Baginya, sejarahlah yang menyediakan basis untuk menilai pertarungan intepretasi. Sejarah dalam konteks ini bukanlah sejarah riil, melainkan merupakan sebuah horison yang meliputi seluruh intepretasi.

Sejarah dalam kaitannya dengan teks, tidak muncul pada level surface, melainkan terkubur di dalam sebagai political unconscious. Sejarah tidak mudah diakses sehingga perlu diintepretasikan. Sementara intepretasi sendiri berakar pada sejarah. Inilah situasi dialektika yang paling inti dari teori Jameson yang menjadi basis metodologisnya ketika menganalisis banyak karya dan gejala budaya.

\section{Psikoanalisis Jameson}

Selain gagasan Marx, yang sangat krusial untuk dibicarakan ketika menelusuri pemikiran Jameson adalah mode kritik Sigmund Freud yang menjadi salah satu landasan utama karyakarya Jameson. Yang menarik kemudian, Freud dan Marx sebetulnya memiliki landasan metodologis yang sangat berbeda. Freud mengolah hubungan antarindividu, sementara Marx menekankan analisis pada hubungan individu dengan masyarakatnya. Sementara Jameson memadukan dua interest yang berbeda ini dalam satu kombinasi yang otentik.

Ada dua aspek dari Freudianism yang sangat relevan dengan analisis-analisis Jameson yakni ketidaksadaran dan mekanisme represi. Kejiwaan manusia terbagi atas id, ego dan superego. Ego adalah kesadaran diri, sementara superego adalah kekuatankekuatan yang mengendalikan ego. Id merupakan ketidaksadaran atau sesuatu yang ada di bawah sadar, yang tidak terjangkau ego, tetapi mempengaruhi keseluruhan tindakan pemiliknya. Menurut Freud, tugas terapis adalah menggunakan teknik apapun untuk membuka problem-problem yang terletak pada level ketidaksadaran dan membawanya pada level kesadaran di mana problem itu memiliki kesempatan untuk diselesaikan atau dirasionalisasikan.

Jameson menganalogikan fungsi terapis yang dikemukakan Freud itu kepada setiap orang yang melihat teks-teks ataupun gejala budaya. Kritikus bertugas membaca teks dan menemukan sesuatu yang tersembunyi, yakni kode-kode yang merupakan manifestasi dari basis ekonomi politik yang membentuk teks tersebut. Basis ekonomi dan politik itu seringkali tersembunyi dalam karya sastra, tetapi mereka tetap ada, dan butuh ditemukan dengan berkonsentrasi pada teks serta melihatnya seperti Freud berupaya menemukan problemproblem ketidaksadaran (bahkan pada level tertentu, Jameson juga mengikuti analogi Freud ketika meneliti slips of tounge dan mengintepretasi mimpi-mimpi).

Perbedaan antara ketidaksadaran dan kesadaran ini berdampak pada perbedaan dalam menemukan makna. Dalam sebuah teks terdapat dua makna yang ditemukan dalam level yang berbeda, yakni makna yang termanifestasikan dan makna yang laten. Makna yang termanifestasikan ada pada level permukaan, makna yang serta-merta langsung bisa ditangkap dari kejadian, sedangkan makna yang laten adalah makna yang dimungkinkan terlihat ketika kita berhasil membuka masalahmasalah dan kontradiksi-kontradiksi dalam ketidaksadaran.

Menurut Jameson, hubungan antara makna yang termanifeskan dengan yang laten seringkali berkebalikan. Proses keterhubungan ini juga tidak manasuka atau arbitrer. Ada kekuatan yang selalu mengontrol dan membentuk lintasan dari ketidaksadaran menuju ke kesadaran, dari laten menuju manifes, yang oleh Jameson diyakini sebagai kekuatankekuatan historis. 
Selain konsep ketidaksadaran dan kesadaran, gagasan Freud yang juga digunakan oleh Jameson adalah represi. Menurut Freud, represi merupakan mekanisme bertahan secara psikologis, untuk berpikir, merespons atau mendorong segala hal yang sulit diterima atau terlalu menyakitkan bagi kesadaran sehingga kemudian dikubur dalam-dalam di ranah ketidaksadaran. Ini adalah bentuk penolakan yang menghentikan apapun yang bisa menyebabkan kecemasan. Jameson kemudian menerapkan mekanisme represi ini ketika melihat seniman-seniman Barat yang cemas dan kemudian curiga ketika berhadapan dengan seniman-seniman non-Western. Lebih jauh lagi, Jameson melalui analisis ini kemudian memodifikasi pemahaman tentang represi, terutama ketika diterapkan dalam analisis masyarakat dalam kapitalisme.

Represi menurut Jameson memiliki fungsireflektif.Represitidakhanyamenghasilkan efek penghapusan terhadap objek tertentu dalam kesadaran, tetapi juga meninggalkan jejak yang justru memungkinkan kita bisa menelusurinya. Respons negatif kita sebagai bagian proses represi akan menampakkan gejala-gejala yang menuntun kita ke lapisan lebih dalam. Respons negatif seniman Western terhadap yang ada di luarnya atau non-Western (misalnya Afrika) merupakan jalan satu-satunya untuk membongkar kebenaran yang tersimpan dalam ketidaksadaran. Respons negatif itu diperlukan dalam sebuah proses pembongkaran untuk mengetahui bagaimana imperialisme dan eksploitasi bangsa Barat kepada bangsa Afrika terjadi.

Selain tentang represi, apa yang dikemukakan Freud terkait pshycological illness yang berlaku pada individu juga diperluas oleh Jameson untuk melihat gejala yang terjadi dalam masyarakat. Gejala itu menyerang masyarakat kapitalis, dan kritikus Marxis berada pada posisi sebagai terapis sosial yang mengeksplorasi area di mana problem-problem kebobrokan masyarakat modern dikubur dan direpresi dalam-dalam.

Selain menderivasi konsep-konsep Freud, Jameson juga mengadaptasi gagasan
Lacan tentang Yang Riil, yang Simbolik dan Yang Imajiner untuk menerangkan bagaimana hubungan antara sejarah dengan teks-teks yang muncul dalam pengaruhnya. Secara umum, Yang Riil dipahami sebagai segala yang ada sebelum bahasa, sementara Yang Simbolik adalah semua area yang sudah dibahasakan dan Yang Imajiner sebagai ranah tempat mengendap segala hal yang gagal diterjemahkan.

Seperti yang dikemukakan Althusser, Jameson menempatkan Yang Riil dalam konteks marxisme. Menurut Jameson, sejarah disamakan posisinya dengan Yang Riil. Sebab, sejarah tidak bisa secara langsung dipahami melainkan harus melalui manifestasimanifestasi Yang Simbolik (juga Yang Imajiner). Artinya, ketika membaca sebuah karya sastra, Jameson mencontohkan Heart of Darkness-nya Conrad, dibutuhkan orientasi konstan terhadap sejarah. Tidak hanya sejarah Kongo pada abad ke-19, tetapi juga sejarah hidup Joseph Conrad sendiri. Tidak hanya dibutuhkan faktafakta rekam jejak kesejarahan yang kronologis tetapi juga cara sejarah ditampilkan sebagai cerita yang membentuk karya Conrad tersebut. Berdasarkan pemahaman yang sama pula, Jameson melihat sejarah pergeseran kapitalis sebagai The Riil menjadi determinan terhadap bentuk-bentuk sastra dan budaya yang ada di dalamnya.

Jameson memilih pendekatan psikoanalisis sebagai piranti yang melengkapi gagasan-gagasan Marxis-nya karena menurutnya kedua pendekatan ini memiliki struktur konseptual yang analog. Relasi antara teori dan praktiknya, resistensi terhadap kesadaran palsu, dan tujuan untuk melawan semantik yang naif-yang beranggapan bahwa makna dengan mudah ditemukan ketika basis ekonomi dan ketidaksadaran psikologisnya dapat ditengaraimerupakan aspek-aspek yang saling sejajar dalam dua pendekatan itu.

\section{Political Unsconsious}

Unifikasi antara dialektika marxis dan psikoanalisis diaplikasikan dengan sangat komprehensif oleh Jameson melalui analisisnya 
dalam buku Political Unsconscious. Melalui analisis dalam buku ini pula dapat diketahui implikasi metodologis yang digunakan Jameson ketika menerapkan gagasan-gagasannya. Masingmasing bab dalam buku tersebut berisi analisis dengan kecenderungan dan penekanan yang berbeda terhadap setiap konsep Jameson. Walau demikian, seluruh analisis tidak pernah lepas dari keberadaan sejarah dan prosesproses intepretasi yang merupakan pisau utama analisis kritis yang ditawarkan Jameson.

Pada bab pertama, Jameson memfokuskan pembahasannya pada konsep mediasi. Baginya, sebuah narasi bisa menjadi media yang menjembatani pengalaman individu dengan totalitas sosialnya melalui proses-proses yang dinamakan transkode. Mediasi merupakan terma dialektikal klasik untuk sebuah hubungan antara analisis formal atas seni dengan basis sosialnya, atau antara pergerakan internal politik suatu negara dengan basis ekonominya (PU: 39). Mediasi disebut proses dialektik sebab ia selalu bergerak bolak-balik di antara dua objek yang berbeda. Misalnya, konsep dan metode pembacaan yang ditawarkan Jameson bisa memediatori makna yang ada pada level permukaan novel Mansfield Park karya Jane Austen yakni cerita cinta konvensional dengan makna yang dihasilkan dari pembacaan terhadap hal-hal yang terkandung pada level ketidaksadaran teks tersebut, yakni kemunculan kelas borjuis yang terkait dengan isu-isu kepemilikan dan otoritas-otoritas tertentu.

Dalam bangunan teoretik Jameson, narasi itu bisa ada dalam novel, dalam tulisan kritik, dalam buku-buku sejarah, dan dalam bentuk cerita-cerita yang lain. Narasi memiliki kemampuan memediasi sebab menurut Jameson, narasi menyediakan ruang yang komprehensif tanpa mereduksi elemen-elemen teks menjadi elemen idealisme yang statis. Narasi merupakan cerita yang di dalamnya ada secara bersama-sama para protagonis, peristiwa-peristiwa, deskripsi dan elemen tekstual lain. Narasi merupakan bagian dari karya sastra yang memiliki potensi paling besar untuk menghadirkan jejak-jejak ketidaksadaran politis.

\section{Narasi Magis dalam Roman}

Dalam bab dua buku The Political Unconscious yang berjudul "Magical Narratives: On the Dialectical Use of Genre Criticism" Jameson mengeksplorasi dan mengaplikasikan perspektifnya tentang narasi dalam sebuah genre sastra, yakni roman yang memiliki karakteristik narasi fantastik yang khas. Jameson memilih roman sebagai bentuk atau genre sastra yang ideal karena roman mampu menghadirkan narasi utopis yang sama dengan yang dihadirkan paradigma marxisme. Roman yang selalu happy ending memiliki basis motivasi seperti yang dibayangkan Karl Marx. Kata Jameson, the marxian vision of history has been described by some as a "comic" archetype or a "romance" paradigm (PU: 103). Inti dari analisis ini adalah pembuktian yang hendak dilakukan Jameson bahwa dalam bentuk apapun sebuah karya sastra, bahkan yang paling tidak realis sekalipun, tetap mengandung determinasideterminasi sejarah dalam ketidaksadarannya.

Selama ini, kritikus Marxis seringkali menekankan prioritas pertamanya pada teksteks realis, sebab realisme dianggap lebih cocok dalam mengungkapkan hal-hal yang aktual dalam kehidupan sehari-hari. Namun, Jameson melihat bahwa penulis-penulis yang paling realis sekalipun_kala itu adalah Walter Scott, Honore de Balzac dan Theodore Dreisertidak semata-mata mencomot apa adanya atau menulis segala yang dilihat dari kenyataan seperti halnya catatan dokumenter. They drew on 'an exhilarating heterogenity in their raw materials and exploited 'a corresponding versalitily in their narrative apparatus' (PU: 104). Gagasan yang selama ini menganggap bahwa sastra yang sesuai dengan semangat marxisme adalah sastra realis, sementara yang lain hanya sastra eskapis adalah gagasan yang mendasarkan analisisnya pada level surface, pada level consciousness of texts. Jameson mengajak untuk melihat lebih dalam lagi, yakni pada level unconsciousness. Sedemikian eskapis apapun sebuah novel, mereka akan tetap membawa dalam dirinya realitas sosial ekonomi yang membentuknya. Jadi, marxisme berada pada arah yang sejajar dengan apa yang 
dihadirkan dalam roman, yang sama-sama bekerja dengan mekanisme politic happy ending.

Sepertiyang menjadipembahasan diawal tentang konsep-konsep Jameson, maka bebanbeban politik tidak hanya tercermin dalam isi sebuah karya, tetapi justru lebih dominan dalam bentuknya. Genre, bagi Jameson, secara esensial menyiratkan pesan sosio-simbolik. Bentuk adalah ideologi dalam wajah yang sebenar-benarnya secara imanen dan intrinsik (PU: 141). Jameson memperjelas gagasannya itu dengan membuat diagram yang menunjukkan relasi antara bentuk dan isi sebuah karya yang paralel dengan relasi antara base-structure dan superstructure dalam teori Karl Marx. Menurut Jameson, base-structure sama dengan substansi sebuah karya sastra, sejarah dan ideologi yang mengkonstruksikannya, sementara superstructure adalah bentuk sebuah karya.

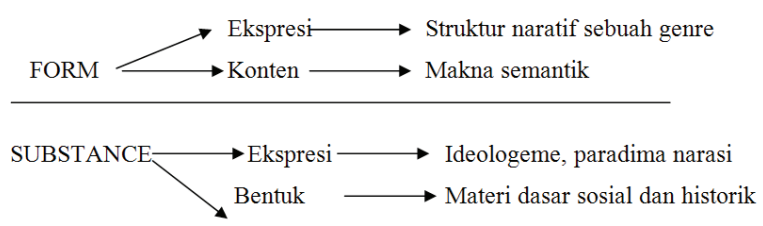

Ideologeme menurut Jameson merupakan satuan terkecil dari ideologi yang bisa menjadi unit analisis ketika menempatkan karya dalam diagram di atas. Ideologeme bisa ditemukan dalam narasi, wacana atau karakterisasi dalam sebuah karya sastra. Jameson memberikan contoh yang merupakan bentuk aplikasi dari diagram di atas ketika menganalisis epik karya Tennyson yang berjudul Idylls of the King. Menurut Jameson, pemilihan bentuk (epik) yang dilakukan Tennyson lebih ideologis dibandingkan penyusunan cerita yang menjadi isinya. Bentuk epik berhubungan sangat dekat dengan perayaan ekspansi patriotik. Epik adalah model nasional, dan Tennyson menulis epik yang merefleksikan Kerajaan Inggris.

Di dalam epik tersebut Tennyson menceritakan kembali mite King Arthur. Epik itu ditulis pada awal 1830an dan belum selesai hingga tahun 1880an. Lamanya waktu yang dibutuhkan oleh Tennyson untuk menulis sama dengan lamanya waktu ekspansi serta konsolidasi yang dilakukan Kerajaan Inggris. Berbeda dengan epik lain yang memiliki kesatuan solid, karya Tennyson ini terfragmentasi menjadi roman berseri yang kemudian digabung dalam berbagai konsistensinya. Fakta ini menarik bagi Jameson. Ia melihat adanya keterkaitan bentuk epik yang terfragmentasi dengan kondisi zaman kala itu. Bentuk yang terkait erat dengan kondisi sosiopolitik di sekitarnya kemudian membawa serta konten yang ideologis, yang direfleksikan dalam narasi-narasi spesifik di dalamnya. Bentuk yang fragmentaris itu kemudian juga paralel dengan cerita dan karakter yang dipaparkan oleh narasi itu. Jameson melihat bentuk itu dalam persamaannya dengan cerita dan karakteristik King Arthur sendiri yang terkenal obsesif, menderita neurotik, dan terlibat dalam masalah pengkhianatan cinta yang merefleksikan secara jernih kecemasan-kecemasan individualisme burjouis serta kontradiksi abad imperialisme.

Dalam skema Jameson, materi dasar sosiohistoris itu sudah membawa dalam dirinya sendiri ketidaksetaraan, sosial fragmentasi, dan alienasi individu dalam kapitalisme. Aspek ini mempengaruhi baik bentuk ataupun isinya. Dalam aspek bentuk, epik yang terfragmentasi memang merupakan keniscayaan kala itu ketika "straight" epik sudah tidak dimungkinkan lagi pada zaman post-Romantik. Dalam aspek isi, seperti kesimpulan Jameson terhadap epik Tennyson, ketika Ratu Guinevere diketahui berselingkuh dan menyebabkan kekacauan di kerajaan pada akhir cerita epik itu, Kerajaan Inggris juga tengah mengalami kemunduran, dan kedua kondisi itu dianggap saling berkaitan.

Jadi, apa yang ada pada aspek isi, bentuk dan kondisi sosial yang membentuknya terjalin dalam sebuah paralelisme yang relasinya timbal balik. Hubungan sekaligus kekompleksan antara dua tataran form dan content itu diperjelas oleh Jameson dalam kalimat, each method, as it moves from the 'form' of a text to the latters relationship to 'substance', completes it self with the complementary term' (PU: 147).

\section{Realisme dan Fantasi dalam Novel}

Dalam bab ketiga buku Political 
Unsconscious yang berjudul "Realism and Desire" Jameson kembali membuktikan, melalui analisisnya terhadap novel The Old Girl karya Honore de Balzac, bahwa di dalam cerita-cerita jenis apapun, dengan mekanisme yang berbeda, akan tetap membawa pembaca pada relasi karya itu dengan sejarahnya. Di dalam novel realis Balzac, Jameson menemukan semacam ilusi yang dalam tataran ketidaksadarannya justru menampilkan sesuatu yang seringkali berlawanan.

Novel ini menyediakan kekuatan melalui gambaran yang detil tentang realitas sebagai bentuk ilusi atas pengalaman hidup yang aktual, yang berhadapan dengan latar belakang lingkungan di mana karya itu diciptakan. Menurut Jameson, kedetilan dan 'kesempurnaan' dalam novel ini bukan hadir sebagai representasi sosial yang apa adanya melainkan menjadi salah satu jenis efek sastra yang menghadirkan fantasi borjuis untuk menunjukkan kemakmuran hidup sebagai sesuatu yang natural. Dalam terma Jameson, utopia hidup makmur yang dihadirkan novel merupakan fantasi novel, percobaan untuk menghindar dari ketegangan atau inkonsistensi dunia aktual yang menjadi pokok atau inti untuk direpresentasi dalam novel Balzac.

\section{Narasi Ideologis}

Jameson juga melihat novel Balzac ini dalam konsep Lacan, bahwa fantasi novel yang hadir merupakan gejala-gejala yang sejalan dengan logika Yang Imajiner. Novel ini menjadi tempat seperti Yang Imajiner di mana upaya menerjemahkan atau respons terhadap Yang Riil muncul dalam bentuk yang beraneka. Jameson kemudian menambah analisis yang sejenis terhadap novel karya George Gissing yang berjudul The Nether World. Jameson menemukan dua narasi besar dalam novel Gissing ini, yaitu tentang filantropis yang berupaya mengubah nasibnya dengan mendonasikan uangnya dan narasi tentang ruang dalam keluarga yang bahagia dan indah yang menjadi pelarian utopis tokoh-tokohnya dari mimpi buruk terkait kelas sosial mereka.
Bagi Jameson, dua narasi itu berujung pada sebab yang sama, dan dua narasi itu sama-sama sudah terdistorsi. Di satu sisi, tokoh yang mewakili dan menjadi bagian dari keluarga yang bahagia tidak menemukan akhir pernikahan yang ia inginkan, sementara sang filantropis, tidak menjadi apapun walau ia sudah mendonasikan seluruh uangnya. Narasi yang harusnya menyimpan semacam resistensi ternyata menurut Jameson sudah sedemikian terdistorsi dan menjadi respon dari yang Simbolik. Ada ideologeme yang bisa disimpulkan dari dua narasi tadi, yang oleh Jameson disimpulkan dalam kalimat, wahai seluruh masyarakat yang ada di kelas rendah: tetaplah berada di tempatmu! Kamu tidak bisa mengubah nasibmu dengan cara apa pun.

Analisis-analisis ringkas Jameson di atas hanyalah sebagian kecil dariuraian mendalamnya dalam buku The Political Unconscious. Ringkasan itu dihadirkan dalam tulisan ini dengan maksud memberikan gambaran dan model analisis. Melalui ringkasan itu akan diketahui bagaimana Jameson mengaplikasikan gagasan Marxis-nya dalam karya sastra. Contoh novel yang ia analisis di atas adalah novel-novel yang lahir pada abadabad modern, dan yang akan diuraikan dengan singkat di bawah ini adalah gagasan Marxis Jameson ketika melihat produk-produk budaya yang dikatakan oleh banyak pemikir lahir pada abad posmodern.

\section{Jameson, Postmodernisme dan Kapitalisme Lanjut}

Ketertarikan Jameson pada fenomena kultural bernama posmodern dimulai pada awal dekade 1980an ketika ia mempublikasikan artikel berjudul "Postmodernism and Consumer Society" yang kemudian diperlengkap dalam artikel berjudul "Postmodernism, or the Cultural Logic of Late Capitalism" yang menjadi esai pertama dalam buku yang berjudul sama.

Yang terpenting ketika menguraikan pemikiran Jameson dalam ranah postmodernisme adalah konsistensinya untuk melihat selalu sebagai seorang Marxis. Ketika 
orang membicarakan posmo sebagai gaya dalam berkesenian, yang pertama dilakukan Jameson ketika melihatnya adalah mengaitkan dengan lingkungan sosio-politik, dengan sejarah. Ketika realisme, dalam terminologi bentuk kesastraan, merupakan perwujudan bentuk dari kapitalisme abad 19, sementara modernisme adalah ekspresi dari proses reifikasi dan kapitalisme posindustrial, maka posmodernisme adalah ekspresi dalam ranah tekstual dan estetik dari pergerakan kapitalisme lanjut.

Kapitalismelanjutadalahlogika ekonomi dan juga kultural. Jameson mengadopsi kategori itu dari ekonom bernama Ernest Mandel, yang merepresentasikan logika ekonomi fase ketiga yang berbeda dari logika ekonomi sebelumnya yang berkembang setelah PD II berakhir. Lalu Jameson meluaskan konteksnya menjadi logika kultural. Sebagai logika kultural maka late capitalism mengandung di dalamnya karakter tradisional dari marxisme (di mana basis mendeterminasi langsung superstruktur) yang dikombinasikan dengan gagasan Althusser dimana pembedaan di antara keduanya adalah problematik. Yang terpenting lagi, ketika posmodernisme muncul dalam gaung yang sporadis, Jameson mencoba untuk memahami, menganalisis, mendemistifikasikannya, daripada merangkul dengan mengejutkan atau menolak cepat-cepat.

Bagi Jameson, seniman atau sastrawan posmodern adalah mereka yang secara konsisten melakukan reaksi terhadap modernisme. Selanjutnya, karya dari seniman itu menunjukkan logika kapitalisme lanjut yang tercermin dalam kekaburan batas-batas misalnya antara yang disebut seni tinggi dengan seni populer. Posmodernism is the erosion of the older distinction between high culture and so-called mass or popular culture (Jameson, 1998: 2). Posmodern kemudian oleh Jameson didefinisikan tidak hanya sebagai aliran atau gaya yang khusus, tetapi lebih sebagai konsep periodik yang berkorelasi dengan kehidupan sosial tipe baru dan tatanan ekonomi yang baru pula (Jameson, 1998: 3).
Fitur-fitur posmodern yang menjadi fokus pembicaraan Jameson dalam kaitannya dengan seni dan karya sastra ada dua, yakni schizofrenia dan pastiche (Jameson, 1998:3). Konsep skizofrenia yang dipahami Jameson diambil dari konteks Lacanian dan konsep yang dirumuskan Gilles Deleuze. Skizofrenia dalam terma Lacan berarti hancurnya atau terputusnya rantai penanda (Jameson, 1991:26). Sementara itu, Deleuze dalam bukunya AntiOedipus (1983) memahami skizofrenia sebagai tahap terlepasnya subjek dari dimensi apapun, tanpa bisa dinamai atau dimaknai lagi. Kondisi skizofrenia ini menciptakan suasana yang membentuk karakteristik tersendiri pada karya seni dan sastra. Seni posmodern menurut Jameson dibentuk oleh karakter ironi dan cynisism, oleh pembebasan dari segala bentuk perasaan dan kecenderungan.

Kondisi skizofrenik ini berujung pada konsep kedua Jameson dalam ranah posmodern, yakni pastiche. Konsep pastiche digunakan untuk melihat karya yang meniru baik bentuk maupun gaya dari karya yang lain. Jameson meyakini karya seni dan sastra pada abad posmodern didominasi oleh karya-karya pastiche. Ia mencontohkan film Blade Runner besutan Ridley Scott sebagai bentuk pastiche sempurna. Di dalam film itu banyak idiom visual yang futuristik tetapi juga ikon-ikon retro film noir yang trendi di dekade 1930an. Dalam beberapa bagian, film ini bergerak dalam alur maju, di bagian yang lain film bergerak mundur. Semua yang ditampilkan Scott dalam analisis yang lebih rinci menurut Jameson tidak dimaksudkan untuk menghadirkan satu poin spesifik terkait dengan masyarakat di mana film itu lahir. Semua campur aduk dan ulang alik itu bekerja di level permukaan sebagai gaya. Karakteristik yang demikian, jika diurai lebih lanjut, terkait erat dan akan selalu demikian dengan kondisi kapital serta sistem ekonomi yang ada sebagai landasan semua proses produksi kesenian di era posmodern.

Review singkat tentang posmodernisme yang dipahami Jameson ini tidak dimaksudkan untukmenguraikan dengan detildanmenyeluruh 
aspek-aspek yang ada di dalamnya. Uraian ini hanya dimaksudkan untuk menunjukkan konsistensi gagasan Marxis yang digunakan Jameson untuk melihat seluruh fenomena dan berbagai kemungkinan pergeseran budaya dalam hubungannya dengan struktur dasar yang memungkinkan fenomena-fenomena itu ada.

\section{Kesimpulan}

Berdasarkan uraian singkat di atas, struktur gagasan dan cara analisis Jameson dalam melihat karya sastra, yang selama ini jarang diformulasikan dengan runut akan coba distrukturkan kembali. Sebuah karya sebagai bagian dari superstruktur, tidak bisa dilepaskan dari struktur dasar yang membentuknya. Namun hubungan di antara keduanya bukanlah merupakan hubungan deterministik sederhana. Pergerakkan struktur dasar yang didominasi oleh aspek ekonomi dan kapitalisme membentuk semacam sejarah. Jameson kemudian merelasikan karya sastra secara khusus dengan aspek sejarah yang membentuknya. Pengaruh sejarah ada dalam sebuah karya sastra pada level unconsciousness. Jameson mensejajarkan karya seperti individu dalam pengertian Freud yang memiliki tataran kesadaran dan ketidaksadaran. Untuk menemukannya diperlukan intepretasi. Tindakan intepretasi untuk menemukan pengaruh sejarah dalam karya sastra juga ditentukan oleh sejarah itu sendiri. Oleh karena itu, proses intepretasi selalu adalah proses dialektik. Semua proses di atas dilakukan pertama-tama dan utama pada ranah bentuk karya sastra. Kemudian baru beralih pada isinya.

Karya sastra yang dianalisis itu diyakini selain merupakan manifestasi sejarah yang membentuknya, juga memiliki potensi resistensi yang tinggi karena bisa mendedahkan atau membongkar kondisi yang sebenarnya dari sejarah yang selama itu direpresi dalam ketidaksadaran. Jejak-jejak represi dalam ketidaksadaran justru membawa pembaca pada temuan-temuan yang otentik. Jejak-jejak itu tampak pada narasi atau ideologeme yang ada pada level permukaan karya. Di sinilah fungsi sastra dan seni dalam upaya untuk membongkar proses-proses dehumanisasi yang dilakukan kapitalisme sebagai roh yang menghuni stuktur dasar kehidupan.

Jika disusun dalam sebuah urutan kerja, maka dalam mengaplikasikan teori Fredric Jameson, untuk menganalisis kesastraan Indonesia misalnya, langkah-langkah yang diperlukan adalah sebagai berikut.

1. Menentukan karya sastra dan sejarah (struktur dasar) umum yang membentuknya;

2. Melakukan analisis terhadap bentuk karya sastra;

3. Menemukan narasi-narasi atau ideologeme yang mencerminkan maknamakna termanifestasi di dalam karya;

4. Jejak-jejak narasi di atas menjadi jalan menuju ke level ketidaksadaran untuk menemukan makna-makna laten karya tersebut yang bisa sangat berkebalikan;

5. Melakukan pembacaan dialektik terhadap temuan-temuan pada level unconscious dengan pertimbangan dari wacana sejarah yang membentuknya;

6. Merumuskan kemungkinan bentuk resistensi atau justru ketertundukan mulai dari aspek bentuk, isi pada tataran surface hingga yang paling dalam dari karya tersebut.

Dari keseluruhan langkah di atas, ada beberapa bagian yang sebenarnya membutuhkan penjelasan dan alat analisis tambahan. Jameson tidak pernah menerangkan bagaimana cara untuk menemukan dan menformulasikan ideologeme dari dalam teks. Ia juga tidak pernah secara eksplisit membuat garis tegas, pada bagian mana letak level ketidaksadaran teks dan bagian-bagian mana dari sebuah teks yang menyusun level kesadarannya. Oleh karena itu, penerapan konsep-konsep Jameson yang mungkin dilakukan membutuhkan sebuah eksplorasi dan bahkan kombinasi metodologis dengan konsep analitik lain yang sejalan agar menciptakan satu kerangka analisis yang lengkap dan utuh. 


\section{Daftar Pustaka}

Adorno, Theodor. 1990. Negative Dialectics (Trans. E.B. Ashton). London and New York: Routledge.

Deleuze, Gilles and Felix Guattari. 1983. Anti-Oedipus: Capitalism and Schizofrenia. Minneapolis: University of Minnesota Press.

Jameson, Fredric. 1971. Marxism and Form. Princeton: Princeton University Press.

Jameson, Fredric. 1981. The Political Unconscious: Narrative as a Socially Symbolic Act. London and New York: Routledge.

Jameson, Fredric. 1991. Postmodernism, or, The Cultural Logic of Late Capitalism. London: Verso.

Jameson, Fredric. 1992. The Geopolitical Aesthetic: Cinema and Space in the World System. Bloomington: Indiana University Press.

Jameson, Fredric. 1994. The Seeds of Time. New York: Columbia University Press.

Jameson, Fredric. 1998. The Cultural Turn: Selected Writtings on Postmodern 1983-1998. London: Verso

Robert, Adam. Fredric Jameson. London and New York: Routledge. 